\title{
Victor Burns Angry Letters
}

I just burned some angry letters that I wrote to Barbara,

Just killed the desolation that I made with my fingers and buried on a shelf,

I just murdered myself.

My hands became smoke, my brain became an exploded bomb,

I wrote the letters when it was raining in my mind

Even though the sun was making leaves into light ponds.

I wrote them when I was not talking to women,

When I was walking away from children.

I just burned the angry diary of what I am.

I became a school yard man. A boy of basketballs,

A cat, happy to be looking at walking dogs,

I became my brother who has already been

Burned after death to the wind singing none of his songs.

I became wet grass, a crack on the picnic table in my yard,

I was the first word I wrote to you, and I became the last.

I became the quilt on my bed.

I jumped off the bridge of my mind and out of its past,

I turned to the silence that is the mass the living sing for the dead.

It is Sunday afternoon in early June,

The happy family I am following next to the Iowa River

Is telling the truth. Barbara's birthday coming soon

Is the reason the hunting dogs in my brain

Have stopped their pursuit,

Her yellow love kite flying for the sky

Is the reason I am looking up and shielding my eyes,

This is the writing book of light,

This is the beginning of the week ending,

This is the window opened to cool air at night,

This is the breakfast the sun brings because it is starting to rise. 
Barbara will sail on her soul in Europe for weeks,

But listening, alone in Iowa,

To the way the new green in the parks in Iowa City speaks,

Knowing how the air in my lungs survives,

I try to write for fire,

But when I walk and the floor creaks,

I listen, spit out words, and sit still for desire. 